\title{
Evaluation of glucose dose on intravenous glucose tolerance test traits in Holstein-Friesian heifers
}

\author{
L. Antonio González-Grajales, ${ }^{*} \dagger$ Laura Pieper, ${ }^{*}{ }^{1}$ Sebastian Mengel, ${ }^{*}$ and Rudolf Staufenbiel \\ ${ }^{*}$ Ruminant and Swine Clinic, Free University of Berlin, 14163 Berlin, Germany \\ †Technologie und Produktentwicklung Dr. Pieper GmbH, 16818 Wuthenow, Germany \\ flnstitute for Veterinary Epidemiology and Biostatistics, Free University of Berlin, 14163 Berlin, Germany
}

\begin{abstract}
Glucose metabolism in dairy and beef cattle has received considerable attention because balanced blood glucose is essential for numerous processes, such as milk production and general health. The glucose tolerance test measures the ability of an organism to regulate blood glucose levels. Glucose half-life time (GHLT) has high heritability and could serve as a potential parameter to breed for metabolic resistance. However, studies focusing on identification of an adequate glucose dose have not yet been conducted in cattle. The objective of this study was to analyze the effect of 5 different glucose doses $(0.5,1,1.5,2$, and $3 \mathrm{~g} / \mathrm{kg}$ of body weight ${ }^{0.75}$ ) on intravenous glucose tolerance test (ivGTT) traits and insulin responses in nongestating heifers. A total of 150 tests were performed in $30 \mathrm{Hol}-$ stein-Friesian heifers aged 13 to 15 mo. Blood samples were obtained every 7 min after glucose injection until min 63. Glucose traits and insulin parameters included blood serum glucose and insulin concentration at min 0 (basal concentration), min 7 to 21 (peak glucose and insulin concentration), and min 63 (last sampling) relative to glucose administration, glucose and insulin area under the curve (GAUC and IAUC), and GHLT estimated between min 14 and 42. Serum glucose and insulin concentrations were measured according to the hexokinase colorimetric method and radioimmunoassay, respectively. Generalized linear mixed model was used to test for significant differences in ivGTT traits, insulin responses, and glucose elimination rates $(k)$ over time at different glucose doses. Maximum glucose and insulin concentrations at min 63 increased with higher glucose doses. Significantly lower GHLT were obtained at increasing glucose doses, whereas GAUC and IAUC were significantly higher at increasing doses. The $k$ values were affected by glucose dose and by time inter-
\end{abstract}

Received May 23, 2017.

Accepted August 29, 2017.

${ }^{1}$ Corresponding author: laura.pieper@fu-berlin.de val. Glucose dose greatly affected most ivGTT traits, insulin responses, and glucose elimination rates. Therefore, researchers should standardize their methods to achieve repeatable results and use the same time points for GHLT calculation. Higher glucose doses $(\geq 1.5 \mathrm{~g} /$ $\mathrm{kg}$ of body weight ${ }^{0.75}$ ) triggered glucose concentrations above the glucose renal threshold during the initial 42 min, whereas the lowest glucose concentration failed to induce a maximum insulin response. Further research is necessary to determine an adequate dose inducing maximum insulin responses with minimum renal glucose losses.

Key words: glucose half-life time, insulin, metabolism, glucose tolerance test

\section{INTRODUCTION}

Carbohydrate metabolism has been largely studied in cows because of the essential role that glucose plays in milk synthesis (reviewed by Aschenbach et al., 2010). Insulin is responsible for promoting glucose uptake in numerous tissues expressing insulin-responsive glucose transporters, whereas tissues with high energy demands, such as the mammary gland, use insulin-independent uptake mechanisms (Komatsu et al., 2005). Monitoring insulin responses through an intravenous glucose tolerance test (ivGTT) is a routine diagnostic tool used to estimate insulin resistance (De Koster and Opsomer, 2013). Commonly, this procedure uses direct quantification of insulin and metabolites or more complex analyses including mathematical modeling (Boston et al., 2006). The test also provides information to assess the influence of specific diets or medical treatments on glucose metabolism and general health status (Sumner et al., 2007; Grünberg et al., 2011). Furthermore, Pieper et al. (2016) found high heritability for some ivGTT traits, such as glucose half-life time (GHLT) in young Holstein bulls, which is related to glucose clearance times from the body. Other parameters derived from the test are influenced by numerous factors besides individual variation (González-Grajales et al., 2017). As suggested by Pieper et al. (2016), GHLT might be used 
in the future as a selection criterion to predict animal health due to the development of numerous conditions in dairy cattle as a result of impaired carbohydrate and lipid metabolism (Drackley et al., 2005). Further studies in this field should aim for a standardization of the test and identification of confounding factors that might alter insulin secretion and glucose utilization rates, such as diet composition (Mears, 1993), fasting times (Kremer, 2008), and glucose dose (Kaneko, 1997).

In young bulls, the glucose tolerance test consists of an intravenously administered glucose solution followed by blood collections every $7 \mathrm{~min}$ after injection within 1 to $2 \mathrm{~h}$ (Freyer et al., 2004), whereas in lactating cows the examination is commonly extended for $2 \mathrm{~h}$ (Hötger et al., 2013). It has been reported that the total glucose amount administered i.v. to ruminants is weight dependent (Kaneko, 1997). Moreover, to our knowledge, the effects of different glucose doses on insulin responses and glucose turnover rates in the same individual are currently unknown. Doses have been calculated on the basis of BW and metabolic BW $\left(\mathbf{B W}^{0.75}\right)$ and ranged from 0.15 (Hashemzadeh-Cigari et al., 2015) to $0.5 \mathrm{~g} /$ $\mathrm{kg}$ of BW (Kerestes et al., 2009) and from 0.15 (Hayirli et al., 2001) to $1 \mathrm{~g} / \mathrm{kg}$ of $\mathrm{BW}^{0.75}$ (Hötger et al., 2013). These inconsistencies are illustrated in current studies implementing ivGTT in Holstein females (Table 1). Conversely, in human medicine, glucose is administered orally at a fixed dose of $75 \mathrm{~g}$ following guidelines by the World Health Organization (Andersen et al., 2016). Thus, data analyses could be appropriately interpreted because glucose dose is very similar among studies. The lack of standardization of glucose dose in cattle studies (e.g., bulls, heifers, or cows) might lead to misinterpretation due to poor stimulatory insulin responses or prolonged hyperglycemic states. It is imperative to investigate the effect of different glucose doses on glucose tolerance test responses and carefully revise factors that might affect the responses to the glucose dose such as age, plane of nutrition, and physiological state. Therefore, we hypothesized that ivGTT traits and insulin responses vary depending on the glucose dose administered to nongestating heifers. The objective of this study was to determine the influence of 5 different glucose doses on glucose traits, insulin responses, and glucose turnover rates $(\boldsymbol{k})$.

\section{MATERIALS AND METHODS}

\section{Heifers}

Nongestating Holstein-Friesian heifers $(\mathrm{n}=30)$ were purchased from a commercial farm located in Northern Germany. Clinical examinations and blood collections were conducted in the same farm as a routine procedure. At the beginning of the study, females weighed $422.5(\mathrm{SD} \pm 33.1 \mathrm{~kg})$ and were 13 to 15 mo old. Animals

Table 1. Intravenous glucose tolerance test studies using different doses in female Holstein-Friesians ${ }^{1}$

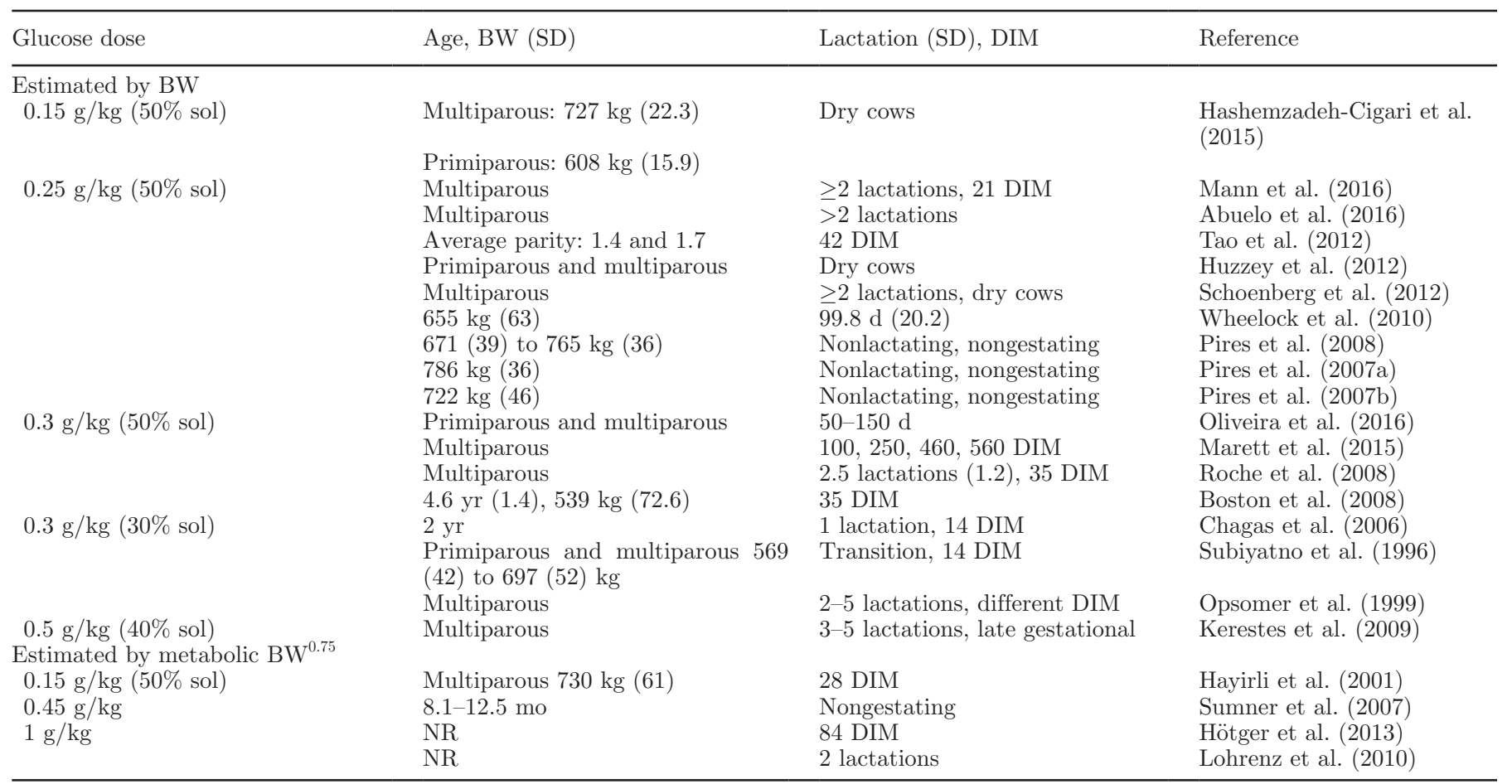

\footnotetext{
${ }^{1}$ Sol $=$ solution; $\mathrm{NR}=$ not reported.
} 
were kept in a free stall with headlocks on rubber bedding surface. Animals were fed a TMR consisting of grass silage, corn silage, rapeseed meal, and a mineral mixture. Feed composition ( $\mathrm{g} / \mathrm{kg}$ of DM) included: $\mathrm{CP}$ (120), Ca (5.5), P (2.8), Mg (1.2), and Na (1.0), providing $10.5 \mathrm{ME}$ of $\mathrm{MJ} / \mathrm{kg}$ of DM.

\section{Study Design}

A total of 30 heifers were used in this study. Animals were assigned to 5 groups in a crossover design conducted during the months of September and October. Each individual was subjected to a total of 5 ivGTT, each time employing a different glucose dose (i.e., $0.5,1,1.5,2$, or $3 \mathrm{~g} / \mathrm{kg}$ of $\mathrm{BW}^{0.75}$ ). In a $420-\mathrm{kg}$ heifer, these doses would be equivalent to doses of 0.11 , $0.22,0.33,0.44$, and $0.66 \mathrm{~g} / \mathrm{kg}$ of $\mathrm{BW}$, respectively. Heifers were tested once per week every 7 to $8 \mathrm{~d}$ at 0600 h. In addition, fasting was implemented for 12 $\mathrm{h}$ before ivGTT and water was available at all times. A total of 150 ivGTT were carried out. The protocols used in this study were approved and supervised by the Ethical Committee on animal welfare authority of Mecklenburg Western Pomerania, Germany (protocol number LVL M-V/310-4/7221.3-2.1-018/03 and LVL $\mathrm{M}-\mathrm{V} / 310-4 / 7221.3-2.1-019 / 03)$.

\section{Intravenous Glucose Tolerance Test}

Animals were weighed and tied approximately $1 \mathrm{~h}$ before blood collection. An intravenous $14 \mathrm{G} \times 8 \mathrm{~cm}$ catheter Vasofix Braunüle (B Braun Melsungen AG, Melsungen, Germany) was placed into the jugular vein and fixed to the skin using a single s.c. suture loop. Blood samples were collected before glucose infusion to determine basal insulin and glucose concentrations. Glucose was administered i.v. as a $40 \%$ solution (B Braun Melsungen AG) to reach the aforementioned doses. Total glucose volume was infused with a selffilling syringe Vet-Matic (Henke Sass Wolf, Tuutlingen, Germany) within 1 min. To avoid potential contamination of blood samples with infused glucose, the catheter was flushed with $15 \mathrm{~mL}$ of $0.9 \% \mathrm{NaCl}$ (Isotone Kochsalz-Lösung, B Braun Melsungen AG) into the jugular vein. A total of 10 samples were obtained every 7 min within $1 \mathrm{~h}$ after glucose administration. Samples were collected in 10-mL serum collection tubes (Kabe Labortechnik, Nümbrecht-Elsenroth, Germany) and centrifuged within $2 \mathrm{~h}$ after collection at 2,000 $\times g$ for $10 \mathrm{~min}$ at room temperature. Serum was stored at $-18^{\circ} \mathrm{C}$ until needed.

Serum glucose concentration was determined with the Gluco-quant Glucose/HK Cobas hexokinase test (Roche Diagnostics GmbH, Mannheim, Germany) according to the manufacturer's instructions (https://usdiagnostics .roche.com/products/05168791190/PARAM49/overlay .html). Solid-phase RIA was used to quantify serum insulin concentration as described by Kremer (2008). Glucose and insulin concentrations were measured every $7 \mathrm{~min}$ relative to glucose administration: basal glucose concentration before glucose administration (G0), peak glucose concentration assessed at $7 \mathrm{~min}$ after i.v. glucose injection (GMAX), GHLT determined between 14 and $42 \mathrm{~min}$, glucose area under the curve (GAUC), and glucose concentration at min 63 (G63). Four insulin responses were analyzed: basal insulin concentration before glucose injection (Ins0), peak insulin concentration reached between 7 and 21 min after i.v. glucose injection (InsMax), insulin concentration at the end of the ivGTT (Ins63), and insulin area under the curve (IAUC). The GAUC and IAUC were calculated with the trapezoidal method. The GHLT was estimated as described by Kaneko (1997) and Pieper et al. (2016) using the time points 14 and 42 min relative to glucose injection. Glucose turnover rates were also calculated according to the following formula:

$$
k=[\ln (\mathrm{G} 1)-\ln (\mathrm{G} 2)] /(\mathrm{T} 2-\mathrm{T} 1) \times 100(\% \text { per min }),
$$

where G1 and G2 represent the glucose concentration at min 14 and 42 after glucose administration, respectively. The second part of the formula $(\mathrm{T} 2-\mathrm{T} 1)$ is equivalent to the time difference between min 14 and 42. In this study, $k$ values were additionally calculated for each consecutive time interval after glucose administration starting at min 7 to determine changes in $k$ over time. We calculated $k$ values for 7 to 14,14 to 21 , 21 to 28,28 to 35,35 to 42,42 to 49,49 to 56 , and 56 to $63 \mathrm{~min}$.

\section{Statistical Analysis}

Glucose traits, insulin responses, and $k$-values were analyzed for normal distribution through graphical methods and normality tests including Shapiro-Wilk test. Data from almost all assessed variables were normally distributed except Ins63. Therefore, base-10 logarithmic transformation was applied to this variable (Ins63) for further analysis. Descriptive statistics were expressed as mean and 95\% confidence interval for insulin responses, and mean and standard error for glucose traits and turnover rates. The total number of observations was 150 and for some variables, 1 or 2 observations were excluded from the analyses when extreme deviations were found (more than 2.5 SD compared with the group mean). Sample size is detailed in Tables 2, 3, and 4. To test for differences in glucose traits and insulin responses among glucose doses, gen- 
Table 2. Predicted means from linear mixed models for intravenous glucose tolerance test traits depending on glucose dose

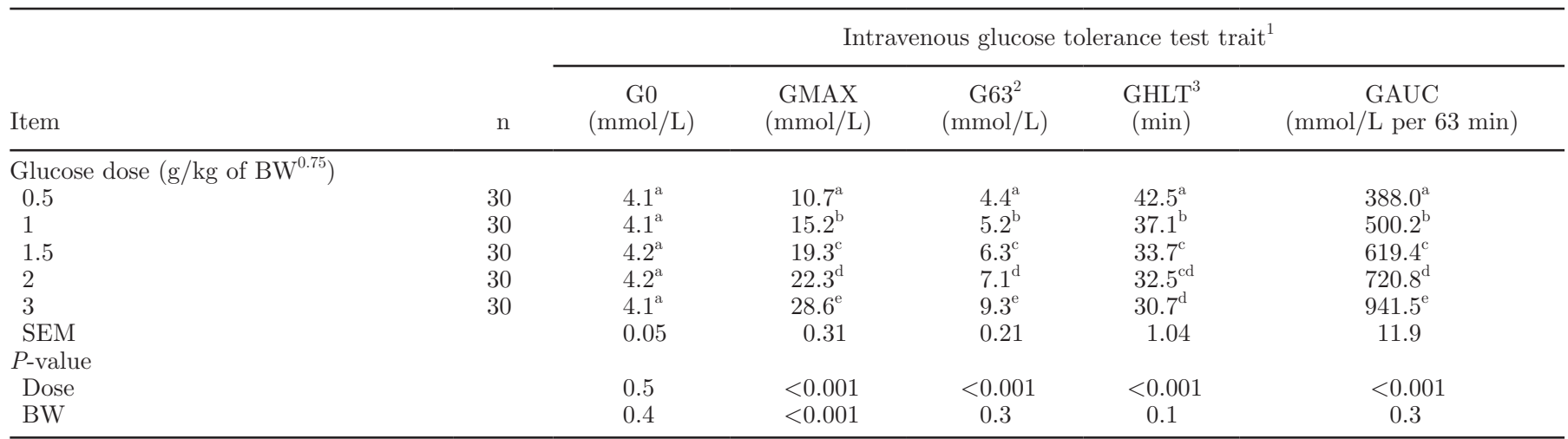

${ }^{\mathrm{a} e}$ Different superscripts indicate significant differences at $P<0.05$.

${ }^{1} \mathrm{G} 0=$ basal glucose concentration before infusion; GMAX = maximum increase in blood glucose concentration; G63 = glucose concentrations at the end of the test relative to glucose injection; GHLT = glucose half-life time; GAUC = glucose area under the curve.

${ }^{2} \mathrm{G} 63$ values for treatment dose $0.5 \mathrm{~g} / \mathrm{kg}^{0.75}$ were estimated based on $\mathrm{n}=29$.

${ }^{3} \mathrm{GHLT}$ values for treatment dose 0.5 and $1 \mathrm{~g} / \mathrm{kg}{ }^{0.75}$ were estimated based on $\mathrm{n}=29$.

eralized linear mixed models were implemented using BW as a confounding variable. For $k$ values, time interval, glucose dose, and an interaction between time interval and glucose dose were tested using a linear mixed model. Animal was included as a random effect in all mixed models to account for repeated measurements in the same animal. Bonferroni test was selected to detect differences among groups. Residuals were analyzed for outliers, homoscedasticity, and normal distribution. The computer program SPSS Statistic version 22 (IBM
Deutschland GmbH, Ehningen, Germany) was employed to carried out statistical analyses and a $P$-value $<0.05$ was considered significant.

\section{RESULTS}

Glucose concentrations during ivGTT are presented in Figure 1. While G0 was not influenced by treatment $(P=0.5)$, all glucose traits derived after glucose administration were significantly affected $(P<0.001)$ by

Table 3. Predicted means from linear mixed models for insulin responses to an intravenous glucose tolerance test traits depending on glucose dose

\begin{tabular}{|c|c|c|c|c|c|}
\hline \multirow[b]{2}{*}{ Item } & \multirow[b]{2}{*}{$\mathrm{n}$} & \multicolumn{4}{|c|}{ Insulin response $^{1}$} \\
\hline & & $\begin{array}{c}\text { Ins0 } \\
(\mu \mathrm{IU} / \mathrm{mL}), \\
\text { mean }[95 \% \mathrm{CI}]\end{array}$ & $\begin{array}{c}\mathrm{InsMax}^{2} \\
(\mu \mathrm{IU} / \mathrm{mL}), \\
\text { mean }[95 \% \mathrm{CI}]\end{array}$ & $\begin{array}{c}\mathrm{Ins} 63^{3} \\
(\mu \mathrm{IU} / \mathrm{mL}), \\
\text { mean }[95 \% \mathrm{CI}]\end{array}$ & $\begin{array}{c}\text { IAUC }^{4} \\
(\mu \mathrm{IU} / \mathrm{mL} \text { per } 63 \mathrm{~min}) \\
\text { mean }[95 \% \mathrm{CI}]\end{array}$ \\
\hline \multicolumn{6}{|c|}{ Glucose dose $\left(\mathrm{g} / \mathrm{kg}\right.$ of $\left.\mathrm{BW}^{0.75}\right)$} \\
\hline 0.5 & 30 & $\begin{array}{l}5.3^{\mathrm{a}} \\
{[4.5-6.1]}\end{array}$ & $\begin{array}{l}86.6^{\mathrm{a}} \\
{[67.0-106.3]}\end{array}$ & $\begin{array}{l}4.1^{\mathrm{a}} \\
{[3.6-4.6]}\end{array}$ & $\begin{array}{l}2,056.0^{\mathrm{a}} \\
{[1,328.7-2,783.4]}\end{array}$ \\
\hline 1.5 & 30 & $\begin{array}{l}5.5^{\mathrm{a}} \\
{[4.6-6.3]}\end{array}$ & $\begin{array}{l}130.3^{\mathrm{b}} \\
{[110.6-149.9]}\end{array}$ & $\begin{array}{l}24.3^{\mathrm{c}} \\
{[21.6-27.2]}\end{array}$ & $\begin{array}{l}4,502.8^{\mathrm{cd}} \\
{[3,783.9-5,221.7}\end{array}$ \\
\hline 2 & 30 & $\begin{array}{l}5.2^{\mathrm{a}} \\
{[4.4-6.1]}\end{array}$ & $\begin{array}{l}143.0^{\mathrm{b}} \\
{\left[123.3^{-162.7}\right.}\end{array}$ & $\begin{array}{l}35.0^{\mathrm{d}} \\
{[31.1-40.0]}\end{array}$ & $\begin{array}{l}5,091.5^{\mathrm{de}} \\
{[4,372.6-5,810.5]}\end{array}$ \\
\hline 3 & 30 & $\begin{array}{l}5.6^{\mathrm{a}} \\
{[4.8-6.4]}\end{array}$ & $\begin{array}{l}148.0^{\mathrm{b}} \\
{[128.1-167.9]}\end{array}$ & $\begin{array}{l}44.5^{\mathrm{d}} \\
{[39.7-50.0]}\end{array}$ & $\begin{array}{l}5,844.6^{\mathrm{e}} \\
{[5,125.6-6,563.6]}\end{array}$ \\
\hline \multicolumn{6}{|c|}{$P$-value } \\
\hline
\end{tabular}

${ }^{\mathrm{a} e}$ Different superscripts indicate significant differences at $P<0.05$.

${ }^{1}$ Ins0 = basal insulin concentration before glucose infusion; InsMax = maximum increase in blood insulin concentration; Ins63 = insulin concentrations at the end of the test relative to glucose injection; IAUC = insulin area under the curve.

${ }^{2}$ InsMax values for glucose dose $3 \mathrm{~g} / \mathrm{kg}$ of $\mathrm{BW}^{0.75}$ were estimated based on $\mathrm{n}=29$.

${ }^{3}$ Values for Ins63 were back transformed to their original for representation.

${ }^{4} \mathrm{IAUC}$ values for $0.5 \mathrm{~g} / \mathrm{kg}$ of $\mathrm{BW}^{0.75}$ were estimated based on $\mathrm{n}=29$. 
Table 4. Predicted means from a linear mixed model for glucose turnover rates $(\% / \mathrm{min})$ at different time intervals depending on glucose dose

Time intervals in min relative to the time of glucose injection

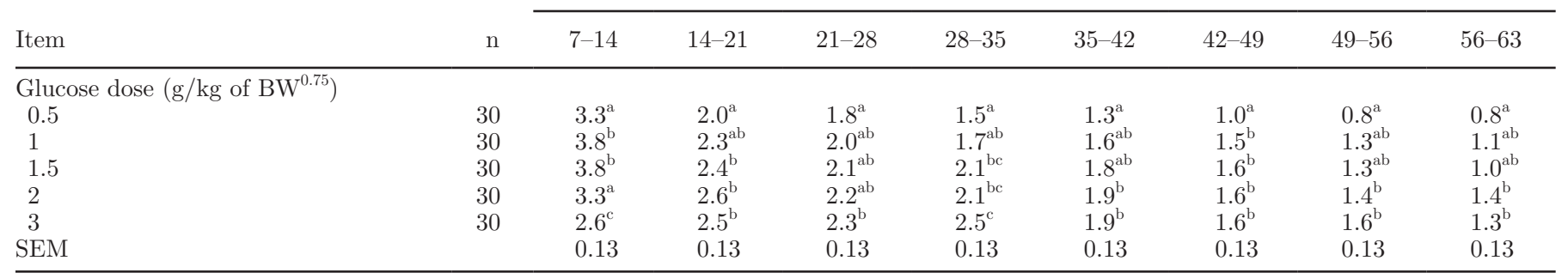

${ }^{a-c}$ Different letters indicate significant differences at $P<0.05$ among glucose doses within time interval. $P$-values: time interval $<0.001 ;$ treatment $<0.001 ;$ time interval $\times$ treatment $<0.001$.

the glucose dose (Table 2). Values for GMAX, G63, and GAUC ranged from 10.7 to $28.6(\mathrm{mmol} / \mathrm{L})$, from 4.4 to $9.3(\mathrm{mmol} / \mathrm{L})$, and from 388.3 to $941.5(\mathrm{mmol} / \mathrm{L} / 63$ min), respectively. Values for these parameters were increasing at increasing glucose doses $(P<0.001)$. Contrarily, GHLT ranged from 30.7 to $42.5 \mathrm{~min}$ with decreasing values obtained at increasing glucose doses $(P<0.001)$.

Serum insulin concentrations over time are shown in Figure 2. Peak insulin concentration ranged from 86.6 to $148.0 \mu \mathrm{IU} / \mathrm{mL}$, occurring within 7 to $21 \mathrm{~min}$ after glucose administration. The overall percentage of heifers exhibiting InsMax at 7, 14, and 21 min after glucose injection was 4, 66, and 30\%, respectively (Figure 3). Insulin concentration at min 63 ranged from 4.1 to 44.5 $\mu \mathrm{IU} / \mathrm{mL}$. Insulin responses were significantly affected $(P<0.001)$ by the glucose dose except Ins0 $(P=0.7$; Table 3). Values for InsMax, Ins63, and IAUC increased with increasing glucose doses $(P<0.001)$. In the case of InsMax, significant differences were only found when

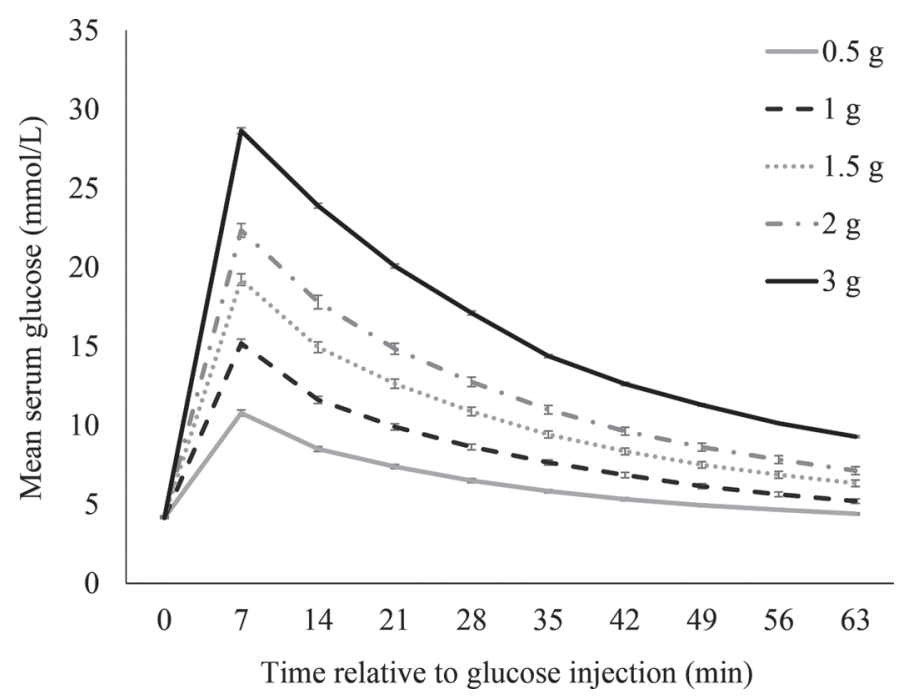

Figure 1. Mean blood serum glucose concentration at different glucose doses $\left(0.5,1,1.5,2\right.$, and $3 \mathrm{~g} / \mathrm{kg}$ of $\left.\mathrm{BW}^{0.75}\right)$. Bars indicate SEM. the dose $0.5 \mathrm{~g}$ was compared with each of the remaining doses. The InsMax did not differ among treatments 1 to $3 \mathrm{~g} / \mathrm{kg}$ of $\mathrm{BW}^{0.75}$. The confounding factor BW had no effects on the parameters analyzed except for GMAX $(P<0.001)$.

Glucose turnover rates were affected by glucose dose $(P<0.001)$, time interval $(P<0.001)$, and glucose dose by time interval interaction $(P<0.001$; Table 4$)$. Except for the time interval 7 to $14 \mathrm{~min}$, the lowest $k$ values were obtained at glucose dose of $0.5 \mathrm{~g}$, whereas higher rates were observed at glucose doses 2 and $3 \mathrm{~g} / \mathrm{kg}$ of $\mathrm{BW}^{0.75}$. The highest $k$ values per group were observed during the first time interval. Between the first and second time interval, a rapid decrease in $k$ values was noticed for all doses except for $3 \mathrm{~g} / \mathrm{kg}$ of $\mathrm{BW}^{0.75}$. The $k$ values were gradually decreasing over time between intervals 14 to 21 and 56 to 63 except for rates derived from animals administered $3 \mathrm{~g} / \mathrm{kg}$ of $\mathrm{BW}^{0.75}$ (Table 4 ), which exhibited a continuous decrease in $k$ values until interval 21 to $28 \mathrm{~min}$, followed by an increase during

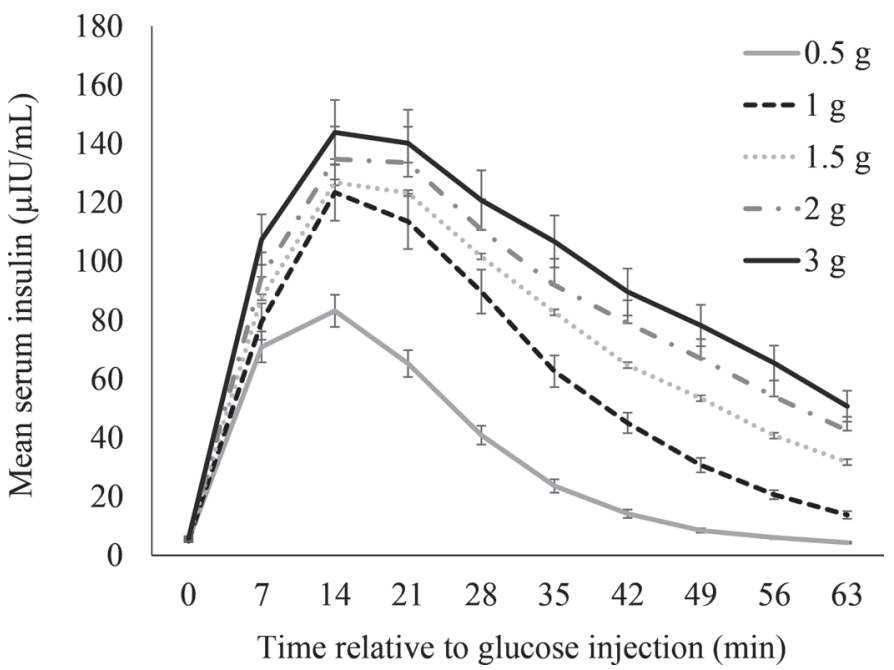

Figure 2. Mean blood serum insulin concentrations at different glucose doses $\left(0.5,1,1.5,2\right.$, and $3 \mathrm{~g} / \mathrm{kg}$ of $\left.\mathrm{BW}^{0.75}\right)$ obtained over $1 \mathrm{~h}$ after glucose administration. Bars indicate SEM. 


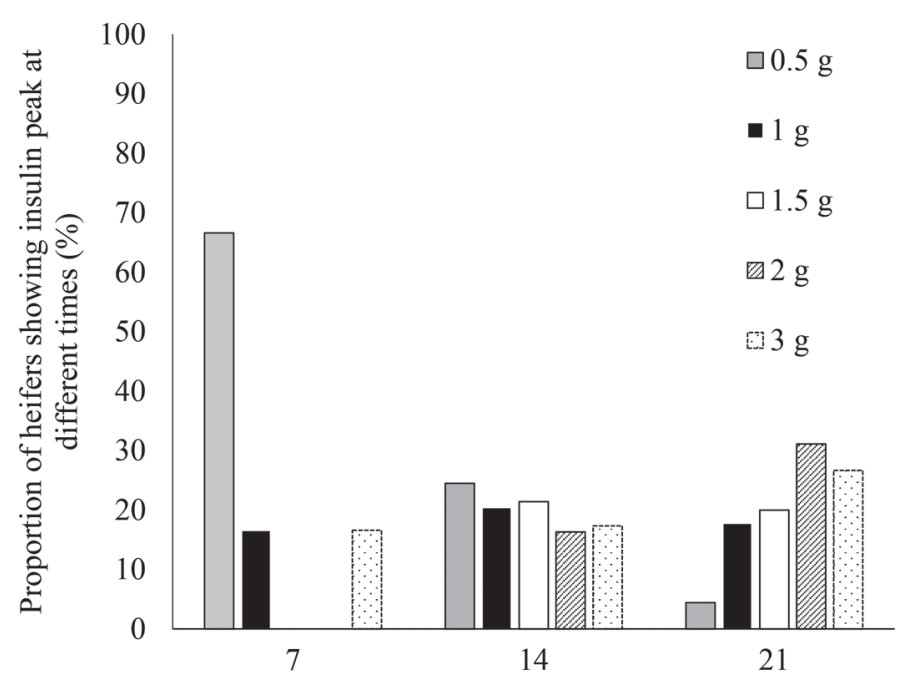

Time relative to glucose injection (min)

Figure 3. Distribution of heifers showing insulin maximum concentration relative to the time of glucose administration at different glucose doses $\left(0.5,1,1.5,2\right.$, and $3 \mathrm{~g} / \mathrm{kg}$ of $\left.\mathrm{BW}^{0.75}\right)$.

the next interval. Thereafter, $k$ continued to decrease similar to the other glucose doses.

\section{DISCUSSION}

The ivGTT is one of the most widely used tests in cattle for assessing carbohydrate homeostasis (De Koster and Opsomer, 2013). Altered glucose and insulin responses relate to pathological and physiological conditions affecting utilization or removal of glucose. Therefore, it is not uncommon to apply this test in research experiments involving nutrition and reproduction, among others fields (Bernhard et al., 2012; Oliveira et al., 2016). Recently, Pieper et al. (2016) determined high heritability $\left(\mathrm{h}^{2}\right)$ for 2 parameters (GHLT and glucose area equivalent), which are variables derived from a glucose tolerance test. Their study suggested that these parameters could be used as a selection criterion for animal health although the test has not yet been standardized in young heifers or bulls. Individual factors influencing a metabolic response (e.g., age, breed, and physiological status) should be carefully revised to obtain reliable results (Kaneko, 1997). Additionally, the effects of fasting (González-Grajales et al., 2017), stress, and diet composition on ivGTT traits in Holstein heifers have also been investigated (Görner, 2011). Surprisingly, little attention has been paid to the effects of glucose dose on ivGTT despite its wide implementation. As a result, several doses have been employed (Table 1) and systematic investigations reviewing the effects on ivGTT traits and insulin responses are lacking. To the authors' knowledge, this is the first study investigating the effects of various glucose doses on ivGTT traits in nongestating Holstein heifers. The findings from our study revealed that almost all parameters derived from the ivGTT were affected by different glucose doses. Similarly, $k$ was also affected by treatment dose and time (Table 4).

Guidelines for ivGTT implementation have previously been documented (Kaneko, 1997). The methodology proposed by this author emphasized the importance of avoiding high glucose doses, stimulation of maximum insulin responses, and promoting glucose removal from the bloodstream by tissue uptake rather than renal excretion. Therefore, the selected glucose doses in our study included common doses reported by current literature, ranging from 0.5 to $3 \mathrm{~g} / \mathrm{kg}$ of $\mathrm{BW}^{0.75}$ (Table 1 ). As expected, the glucose dose influenced both glucose ivGTT traits and insulin responses (Tables 2 and 3). The only treatment where glucose (G63) and insulin concentration (Ins63) returned close to baseline within testing time was $0.5 \mathrm{~g} / \mathrm{kg}$ of $\mathrm{BW}^{0.75}$, which is in agreement with a previous report in heifers using 0.45 glucose $\mathrm{g} / \mathrm{kg}$ of $\mathrm{BW}^{0.75}$ (Sumner et al., 2007). Other, studies implementing higher doses have extended blood collections beyond min 63 to determine the time at which glucose concentration reaches baseline (van Meirhaeghe et al., 1988). Thus, the length of sampling time might be chosen based on insulin responsiveness to glucose at different physiological stages (Sano et al., 1993). For instance, lactating cows administered $0.3 \mathrm{~g} / \mathrm{kg}$ of BW (50\% sol) reached baseline concentrations at $160 \mathrm{~min}$ (Subiyatno et al., 1996; Roche et al., 2008; Marett et al., 2015; Oliveira et al., 2016), whereas nonlactating nongestating cows only required $60 \mathrm{~min}$ at $0.25 \mathrm{~g} / \mathrm{kg}$ of BW (Pires et al., 2007b, 2008).

Another relevant parameter assessed during an ivGTT includes peak responses. In our study, the majority of heifers exhibited maximum glucose and insulin concentration at min 7 and 14 after injection, respectively. Interestingly, a considerable percentage of animals (approximately $30 \%$ ) exhibited insulin peaks at min 21 , which might be attributed to individual variation or sustained insulin release as a result of elevated serum glucose concentration (Figure 3). From all ivGTT traits assessed, only GMAX was influenced by BW, which could be related to higher glucose amounts applied as weight increased. The lack of influence of BW on ivGTT traits and insulin responses is in agreement with our previous study on fasting times (González-Grajales et al., 2017). Other studies found an association between degree of obesity and insulin maximum responses (McCann and Reimers, 1986). The variability in tested heifers was likely too small and the duration of our experiments (approximately $4 \mathrm{wk}$ ) was probably not sufficient to detect differences in other parameters as a 
result of BW or BW gain. Maximum glucose response was significantly different between treatment groups, whereas maximum insulin responses differed only when the group receiving $0.5 \mathrm{~g} / \mathrm{kg}$ of $\mathrm{BW}^{0.75}$ was compared with each of the remaining doses (Table 3 ). This finding indicates that the maximum insulin release is likely achieved with $1 \mathrm{~g} / \mathrm{kg}$ of $\mathrm{BW}^{0.75}$. Conversely, a glucose dose of $0.5 \mathrm{~g} / \mathrm{kg}$ of $\mathrm{BW}^{0.75}$ might be insufficient to produce a maximum response in nongestating Holstein heifers. In other species, such as rodents (Frangiodakis et al., 2008) and the domestic cat (Hoenig et al., 2002), evidence has suggested that insulin responses are glucose-dose dependent. The latter study reported significant exponential increases in IAUC with increasing glucose doses ranging from 0.3 to $1.3 \mathrm{~g} / \mathrm{kg}$ of $\mathrm{BW}$ and biphasic insulin secretion only achieved at glucose doses higher than $0.8 \mathrm{~g} / \mathrm{kg}$ of BW. Nevertheless, to the authors' knowledge these particularities have not been described in cattle at higher doses.

One of the main components derived from an ivGTT is the glucose turnover or elimination rate $(k)$, which is defined as the slope of the decline of the natural logarithm of serum glucose between any 2 time points and is indirectly proportional to GHLT $\{$ GHLT $=[\ln (2) / k]$ $\times 100$ (min); Kaneko, 1997\}. Jen and Hansen (1988) reported that high $k$ values are attributed to sudden increases in blood glucose concentrations reached during the first minutes after glucose injection, whereas $k$ calculations considering late time points result in lower values because glucose concentrations are near baseline. Therefore, the high $k$ values obtained from our study at time interval 7 to $14 \mathrm{~min}$ for all treatment groups except $3 \mathrm{~g} / \mathrm{kg}$ of BW ${ }^{0.75}$ support the findings of Jen and Hansen (1988). The reasons for obtaining significantly lower $k$ values in animals receiving the highest dose at the aforementioned time point are currently unknown. The differences might be related to changes in insulin secretion or glucose uptake mechanisms. Insulin is stored in granules that undergo functional changes before its release (reviewed by Wang and Thurmond, 2009). In vitro studies in rodents have revealed that insulin release during the first minutes after glucose stimulus originates from granules classified as immediately releasable, whereas insulin secreted during a second phase occurring 20 min later resulted from recruitment of readily releasable granules (Straub and Sharp, 2002; Wang and Thurmond, 2009). Although there is no literature supporting these processes in bovine species, glucose concentration might play a role in the total number of granules responding to the stimulus, as previously demonstrated in rodents (Grodsky, 1972). Consequently, the lower $k$ value observed in our study a few minutes after glucose administration at the highest dose might be related to depletion of the im- mediately releasable insulin granules with subsequent translocation and stimulation of more readily releasable storages, resulting in a prolonged increase in insulin concentrations over time. Further experiments must investigate this hypothesis because insulin concentrations obtained from our study cannot corroborate the typical biphasic insulin secretion described in other species. Other reports have indicated that delays in glucose uptake by insulin-stimulated tissues might be linked to saturation of the system with glucose (Revers et al., 1983; Baron et al., 1985), which in turn could alter its metabolic clearance rate as observed in our study.

Glucose concentrations between min 14 to 42 are preferred to estimate $k$ values because exponential decreases in glucose levels are expected in healthy individuals (Kaneko, 1997). In our study, consecutive time points starting at min 7 after glucose administration were used to identify variations in $k$ among time intervals and also to determine the influence of glucose dose on glucose turnover rates. Significantly higher turnover rates were observed at higher doses, which could be explained as a regulatory response to decreased glucose concentrations to normal levels within a short time. Studies conducted on healthy dogs have reported significant increases in $k$ with increasing glucose doses up to $1 \mathrm{~g} / \mathrm{kg}$ of BW (Rottiers et al., 1981). Moreover, an increase in $k$ values from time intervals 21 to 28 to 28 to $35 \mathrm{~min}$ in heifers receiving the highest glucose dose was found in our study. This increase in glucose turnover rates could be associated with homeostatic mechanisms to rapidly regulate hyperglycemic states via insulin release in response to glucose (reviewed by Wang and Thurmond, 2009). Additionally, the GHLT values obtained in our study might relate to this mechanism because significantly reduced GHLT was found at increasing glucose doses when compared with heifers administered lower doses. Previous research has shown that glucose disappearance follows a single exponential function at a constant rate in an organism that is not yet overloaded with glucose (Palmquist and Moser, 1981). The $k$ values from our study were different depending on the glucose dose and time interval at which $k$ was estimated. Thus, selection of adequate glucose dose and time points for $k$ determination is essential to obtain repeatable GHLT values.

During a glucose tolerance test, changes in serum glucose concentrations in adult, nonlactating nongestating cattle are influenced by infused glucose solution, carbohydrate synthesis in liver and kidney, uptake by insulin-sensitive tissues, and renal elimination (reviewed by De Koster and Opsomer, 2013). Thus, data interpretation could be challenging because the test does not quantify the involvement of these processes at specific stages. Kaneko (1997) recommended that the influence 
of glucose clearance through the distal renal tubules should be minimized to obtain unaltered ivGTT responses. In cattle, renal threshold for glucose ranges from 5.5 to $7.7 \mathrm{mmol} / \mathrm{L}$ in adult individuals (Stämpfli and Oliver-Espinosa, 2015). It has been estimated that about $8 \%$ of the total glucose amount injected during an ivGTT $(0.4 \mathrm{~g}$ per $\mathrm{kg}$ of BW) is eliminated via urine (Palmquist and Moser, 1981). Although our study did not determine glucose concentration in urine, it was expected that the renal glucose threshold was exceeded for most glucose treatments and times after injection except for $0.5 \mathrm{~g} / \mathrm{kg}$ of $\mathrm{BW}^{0.75}$. Consequently, it might be assumed that less glucose was excreted at lower glucose doses because the amount of glucose transferred into the urine is proportional to the glucose dose (Kaneko, 1997). Thus, the doses 0.5 and $1 \mathrm{~g} / \mathrm{kg}$ of $\mathrm{BW}^{0.75}$ used in this study might elicit less glucose urine losses when compared with $1.5,2$, and $3 \mathrm{~g} / \mathrm{kg}$ of $\mathrm{BW}^{0.75}$. van Meirhaeghe et al. (1988) reported that glucose doses surpassing the glucose renal threshold might cause a $20 \%$ overestimation in glucose half-life times due to glucose overload. Their findings could be explained by the high glucose dose $(0.5 \mathrm{~g} / \mathrm{kg}$ of BW $)$ implemented in their experiments, which emphasizes the importance of carefully selecting an adequate dose because it represents a source of bias. The results from our study clearly evidenced the effect that glucose dose exerts on all parameters derived from a glucose tolerance test. In nongestating young heifers, glucose doses higher than $1 \mathrm{~g} / \mathrm{kg}$ of $\mathrm{BW}^{0.75}$ might facilitate glucose losses in urine rather than tissue utilization. Moreover, the lowest glucose dose was expected to cause less glucosuria, but the maximum insulin response was not achieved with $0.5 \mathrm{~g} / \mathrm{kg}$ of $\mathrm{BW}^{0.75}$. This especially has to be considered when associations between insulin secretion patterns and pathological conditions are anticipated (Opsomer et al., 1999).

\section{CONCLUSIONS}

Standardization of ivGTT should include factors such as glucose dose to improve its repeatability in cattle studies. We demonstrated that glucose dose significantly alters ivGTT traits, insulin responses, and elimination rates $(k)$ in nongestating Holstein heifers. Elimination rates were influenced by glucose dose and changed over time, which emphasizes the importance of selecting the same time period to obtain repeatable results. This is the first study investigating the effects of commonly used glucose doses on ivGTT in Holstein heifers. Although numerous studies on ivGTT have been conducted in cows, extrapolating their findings to heifers might lead to misinterpretation due to the physiological particularities between these 2 groups.
To induce maximum insulin responses with minimal involvement of the kidneys in glucose clearance rates, adequate doses might be found within the range from 0.5 to $1 \mathrm{~g} / \mathrm{kg}$ of $\mathrm{BW}^{0.75}$ in young Holstein-Friesian heifers. Further studies including doses within this range and other confounding factors are necessary.

\section{ACKNOWLEDGMENTS}

We thank Michaela Waberowski (Ruminant and Swine Clinic, Free University of Berlin, Berlin, Germany) for assisting with hormone analyses. This study was partially funded by Technologie und Produktentwicklung Dr. Pieper GmbH, Wuthenow, Germany.

\section{REFERENCES}

Abuelo, A., V. Alves-Nores, J. Hernandez, R. Muiño, J. L. Benedito, and C. Castillo. 2016. Effect of parenteral antioxidant supplementation during the dry period on postpartum glucose tolerance in dairy cows. J. Vet. Intern. Med. 30:892-898.

Andersen, T. R., J. F. Schmidt, M. T. Pedersen, P. Krustrup, and J. Bangsbo. 2016. The effects of 52 weeks of soccer or resistance training on body composition and muscle function in +65-yearold healthy males-A randomized controlled trial. PLoS One 11:e0148236.

Aschenbach, J. R., N. B. Kristensen, S. S. Donkin, H. M. Hammon, and G. B. Penner. 2010. Gluconeogenesis in dairy cows: The secret of making sweet milk from sour dough. IUBMB Life 62:869-877.

Baron, A. D., O. G. Kolterman, J. Bell, L. J. Mandarino, and J. M. Olefsky. 1985. Rates of non-insulin mediated glucose uptake are increased in type II diabetes subjects. J. Clin. Invest. 76:1782-1788.

Bernhard, B. C., N. C. Burdick, R. J. Rathmann, J. A. Carroll, D. N. Finck, M. A. Jennings, T. R. Young, and B. J. Johnson. 2012. Chromium supplementation alters both glucose and lipid metabolism in feedlot cattle during the receiving period. J. Anim. Sci. 90:4857-4865.

Boston, R. C., P. J. Moate, and D. Stefanovski. 2006. Modeling the glucose challenge in dairy cows. Can. J. Anim. Sci. 86:569-570.

Boston, R. C., J. R. Roche, G. M. Ward, and P. J. Moate. 2008. A novel minimal model to describe non-esterified fatty acid kinetics in Holstein dairy cows. J. Dairy Res. 75:13-18.

Chagas, L. M., F. M. Rhodes, D. Blache, P. J. S. Gore, K. A. Macdonald, and G. A. Verkerk. 2006. Precalving effects on metabolic responses and postpartum anestrus in grazing primiparous dairy cows. J. Dairy Sci. 89:1981-1989.

De Koster, J. D., and G. Opsomer. 2013. Insulin resistance in dairy cows. Vet. Clin. North Am. Food Anim. Pract. 29:299-322.

Drackley, J. K., H. M. Dann, N. Douglas, N. A. J. Guretzky, N. B. Litherland, J. P. Underwood, and J. J. Loor. 2005. Physiological and pathological adaptations in dairy cows that may increase susceptibility to periparturient diseases and disorders. Ital. J. Anim. Sci. 4:323-344.

Frangiodakis, G. A., C. Gyte, S. J. G. Loxham, and S. M. Poucher. 2008. The intravenous glucose tolerance test in cannulated Wistar rats: A robust method for the in vivo assessment of glucose- stimulated insulin secretion. J. Pharmacol. Toxicol. Methods 57:106113

Freyer, G., R. Staufenbiel, E. Fisher, and L. Panicke. 2004. Parameters of glucose tolerance test traits in dairy cattle. Arch. Tierz. 49:120-132.

González-Grajales, L. A., L. Pieper, J. Kremer, and R. Staufenbiel. 2017. Influence of food deprivation on intravenous glucose tolerance test traits in Holstein Friesian heifers. J. Dairy Sci. 100:77107719 . 
Görner, P. 2011. Experimentelle Untersuchungen zu fütterungsabhängigen Einflussfaktoren auf die Insulinantwort im Glukosetoleranztest bei Jungbullen, Ochsen und Färsen [in German with English abstract]. Doctoral dissertation, Ruminant and Swine Clinic, Free University of Berlin, Germany.

Grodsky, G. M. 1972. A threshold distribution hypothesis for packet storage of insulin and its mathematical modeling. J. Clin. Invest. 51:2047-2059.

Grünberg, W., S. S. Donkin, and P. D. Constable. 2011. Periparturient effects of feeding a low dietary cation-anion difference diet on acidbase, calcium, and phosphorus homeostasis and on intravenous glucose tolerance test in high-producing dairy cows. J. Dairy Sci. 94:727-745.

Hashemzadeh-Cigari, F., G. R. Ghorbani, M. Khorvash, A. Riasi, A. Taghizadeh, and Q. Zebeli. 2015. Supplementation of herbal plants differently modulated metabolic profile, insulin sensitivity, and oxidative stress in transition dairy cows fed various extruded oil seeds. Prev. Vet. Med. 118:45-55.

Hayirli, A., D. R. Bremmer, S. J. Bertics, M. T. Socha, and R. R. Grummer. 2001. Effect of chromium supplementation on production and metabolic parameters in periparturient dairy cows. J. Dairy Sci. 84:1218-1230.

Hoenig, M., S. Alexander, J. Holson, and D. C. Ferguson. 2002. Influence of glucose dosage on interpretation of intravenous glucose tolerance tests in lean and obese cats. J. Vet. Intern. Med. 16:529 532 .

Hötger, K., H. M. Hammon, C. Weber, S. Görs, A. Tröscher, R. M. Bruckmaier, and C. C. Metges. 2013. Supplementation of conjugated linoleic acid in dairy cows reduces endogenous glucose production during early lactation. J. Dairy Sci. 96:2258-2270.

Huzzey, J. M., R. J. Grant, and T. R. Overton. 2012. Short communication: Relationship between competitive success during displacements at an overstocked feed bunk and measures of physiology and behavior in Holstein dairy cattle. J. Dairy Sci. 95:4434-4441.

Jen, K. L., and B. C. Hansen. 1988. Glucose disappearance rate in rhesus monkeys: Some technical considerations. Am. J. Primatol. 14:153-166.

Kaneko, J. J. 1997. Carbohydrate metabolism and its diseases. Pages 45-81 in Clinical Biochemistry of Domestic Animals. 6th ed. J. J. Kaneko, W. J. Harvey, and L. M. Bruss, ed. Academic Press, San Diego, CA.

Kerestes, M., V. Faigl, M. Kulcsár, O. Balogh, J. Földi, H. Fébel, Y. Chilliard, and G. Huszenicza. 2009. Periparturient insulin secretion and whole-body insulin responsiveness in dairy cows showing various forms of ketone pattern with or without puerperal metritis. Domest. Anim. Endocrinol. 37:250-261.

Komatsu, T., F. Itoh, S. Kushibiki, and K. Hodate. 2005. Changes in gene expression of glucose transporters in lactating and nonlactating cows. J. Anim. Sci. 83:557-564.

Kremer, J. 2008. Einfluss der Dauer der Nüchternzeit auf das Ergebnis im intravenösen Glukosetoleranztest beim weiblichen Jungrind [in German with English abstract]. Doctoral dissertation, Ruminant and Swine Clinic, Free University of Berlin, Germany.

Lohrenz, A. K., K. Duske, F. Schneider, K. Nürnberg, B. Losand, H. M. Seyfert, C. C. Metges, and H. M. Hammon. 2010. Milk performance and glucose metabolism in dairy cows fed rumen-protected fat during mid lactation. J. Dairy Sci. 93:5867-5876.

Mann, S., F. A. L. Yepes, M. Duplessis, J. J. Wakshlag, T. R. Overton, B. P. Cummings, and D. V. Nydam. 2016. Dry period plane of energy: Effects on glucose tolerance in transition dairy cows. J. Dairy Sci. 99:701-717.

Marett, L. C., M. J. Auldist, P. J. Moate, W. J. Wales, K. L. Macmillan, F. R. Dunshea, and B. J. Leury. 2015. Response of plasma glucose, insulin, and nonesterified fatty acids to intravenous glucose tolerance tests in dairy cows during a 670-day lactation. J. Dairy Sci. 98:179-189.

McCann, J. P., and T. J. Reimers. 1986. Effects of obesity on insulin and glucose metabolism in cyclic heifers. J. Anim. Sci. 62:772-782.

Mears, G. J. 1993. Influence of feeding and diet on diurnal patterns of plasma growth hormone and insulin in calves. Can. J. Anim. Sci. 73:987-991.
Oliveira, L. H., A. B. Nascimento, P. L. J. Monteiro, M. M. Guardieiro, M. C. Wiltbank, and R. Sartori. 2016. Development of insulin resistance in dairy cows by 150 days of lactation does not alter oocyte quality in smaller follicles. J. Dairy Sci. 99:9174-9183.

Opsomer, G., T. Wensing, H. Laevens, M. Coryn, and A. de Kruif. 1999. Insulin resistance: The link between metabolic disorders and cystic ovarian disease in high yielding dairy cows? Anim. Reprod. Sci. 56:211-222.

Palmquist, D. L., and E. A. Moser. 1981. Dietary fat effects on blood insulin, glucose utilization, and milk protein content of lactating cows. J. Dairy Sci. 64:1664-1670.

Pieper, L., R. Staufenbiel, J. Christ, L. Panicke, U. Müller, and G. A. Brockmann. 2016. Heritability of metabolic response to the intravenous glucose tolerance test in German Holstein Friesian bulls. J. Dairy Sci. 99:7240-7246.

Pires, J. A. A., J. B. Pescara, A. E. Brickner, N. Silva del Rio, A. P. Cunha, and R. R. Grummer. 2008. Effects of abomasal infusion of linseed oil on responses to glucose and insulin in Holstein cows. J. Dairy Sci. 91:1378-1390.

Pires, J. A. A., J. B. Pescara, and R. R. Grummer. 2007a. Reduction of plasma NEFA concentration by nicotinic acid enhances the response to insulin in feed-restricted Holstein cows. J. Dairy Sci. 90:4635-4642.

Pires, J. A. A., A. H. Souza, and R. R. Grummer. 2007b. Induction of hyperlipidemia by intravenous infusion of tallow emulsion causes insulin resistance in Holstein cows. J. Dairy Sci. 90:2735-2744.

Revers, R. R., O. G. Kolterman, and J. M. Olefsky. 1983. Relationship between serum glucose level and the metabolic clearance rate of glucose in non-insulin dependent diabetes mellitus. Diabetes $32: 627-632$.

Roche, J. R., A. J. Sheahan, L. M. Chagas, and R. C. Boston. 2008. Short communication: Change in plasma ghrelin in dairy cows following an intravenous glucose challenge. J. Dairy Sci. 91:10051010 .

Rottiers, R., D. Mattheeuws, J. J. Kaneko, and A. Vermeulen. 1981. Glucose uptake and insulin secretory responses to intravenous glucose loads in the dog. Am. J. Vet. Res. 42:155-158.

Sano, H., S. Narahara, T. Kondo, A. Takahashi, and Y. Terashima. 1993. Insulin responsiveness to glucose and tissue responsiveness to insulin during lactation in dairy cows. Domest. Anim. Endocrinol. 10:191-197.

Schoenberg, K. M., R. M. Ehrhardt, and T. R. Overton. 2012. Effects of plane of nutrition and feed deprivation on insulin responses in dairy cattle during late gestation. J. Dairy Sci. 95:670-682.

Stämpfli, H., and O. Oliver-Espinosa. 2015. Clinical chemistry tests. Pages 350-373 in Large Animal Internal Medicine. 5th ed. B. P. Smith, ed. Elsevier Mosby, St. Louis, MO.

Straub, S. G., and G. W. G. Sharp. 2002. Glucose-stimulated signalling pathways in biphasic insulin secretion. Diabetes Metab. Res. Rev. 18:451-463.

Subiyatno, A., D. N. Mowat, and W. Z. Yang. 1996. Metabolite and hormonal responses to glucose or propionate infusions in periparturient dairy cows supplemented with chromium. J. Dairy Sci. 79:1436-1445.

Sumner, J. M., F. Valdez, and J. P. McNamara. 2007. Effects of chromium propionate on response to an intravenous glucose tolerance test in growing Holstein heifers. J. Dairy Sci. 90:3467-3474.

Tao, S., I. M. Thompson, A. P. A. Monteiro, M. J. Hayen, L. J. Young, and G. E. Dahl. 2012. Effect of cooling heat-stressed dairy cows during the dry period on insulin response. J. Dairy Sci. 95:50355046 .

van Meirhaeghe, H., P. Deprez, C. van den Hende, and E. Muylle. 1988. Plasma-glucose clearance and insulin-response in cows with abomasal displacement. Zentralbl. Veterinarmed. A 35:221-228.

Wang, Z., and D. C. Thurmond. 2009. Mechanisms of biphasic insulingranule exocytosis-Roles of the cytoskeleton, small GTPases and SNARE proteins. J. Cell Sci. 122:893-903.

Wheelock, J. B., R. P. Rhoads, M. J. VanBaale, S. R. Sanders, and L. H. Baumgard. 2010. Effects of heat stress on energetic metabolism in lactating Holstein cows. J. Dairy Sci. 93:644-655. 